\title{
PERAN ORANG TUA SEBAGAI MITRA GURU DALAM PEMBELAJARAN DARING SELAMA MASA PANDEMI COVID - 19
}

\author{
SUTINI \\ MTs Negeri 2 Temanggung \\ E-mail : sutini.maryoto@gmail.com
}

\begin{abstract}
ABSTRAK
Penelitian ini bertujuan untuk menelaah secara mendalam peran orang tua selama pembelajaran daring berlangsung menggunakan studi pustaka. Tahapan yang dilakukan dalam penelitian ini adalah. Akibat pandemi Covid-19 yang sudah berlangsung selama setahun lebih, dunia pendidikan masih menerapkan kebijakan dari pemerintah untuk melaksanakan pembelajaran secara daring. Dalam pembelajaran secara daring ini tentu saja di lapangan banyak sekali ditemukan masalah yang menyangkut motivasi belajar siswa, ketersediaan sarana dan prasarana dan tingkat keefektifan guru dalam menyampaikan materi, mengingat pembelajaran daring ini tidak terjadi secara tatap muka langsung, sehingga bukan merupakan suatu hal yang mudah bagi anak. Kemandirian anak dalam belajar sangat dituntut, agar dapat mengikuti pembelajaran secara daring ini. Orang tua sebagai orang yang keberadaannya paling dekat dengan anak, mempunyai peran yang sangat penting sebagai mitra guru selama proses pembelajaran berlangsung antara lain sebagai motivator dan pendamping siswa. Selain itu orang tua juga berperan fasilitator yang menyiapkan segala keperluan anak untuk mengikuti pembelajaran daring, dan sebagi guru yang mendampingi proses pembelajaran di rumah
\end{abstract}

Kata kunci : Pandemi Covid-19, Peran orang tua dan pembelajaran daring

\section{THE ROLE OF PARENTS AS TEACHER'S PARTNER IN ONLINE LEARNING DURING THE COVID-19 PANDEMIC PERIOD}

\begin{abstract}
The aim of this study is to examine in depth the role of parents during online learning using literature study. The stages carried out in this study are determination of the topic, observation of literatures, reduction of literatures, review and taking a conclusion of it. As a result of the Covid-19 pandemic which has been going on for more than a year, the world of education is still implementing policies from the government to carry out online learning. In online learning, of course, in the real condition there are many problems related to student learning motivation, the availability of facilities and infrastructure and the level of teacher effectiveness in delivering material, considering that online learning does not occur face-toface, so it is not an easy thing for child. The independence of children in learning is highly demanded, so that they can participate in this online learning. Parents, as the people closest to their children, have a very important role as teacher's partners during the learning process, including as a motivator and student companion. In addition, parents also play a role as a facilitator who prepares everything the child needs to take part in online learning, and as a teacher who accompanies the learning process at home.
\end{abstract}

Keywords : Pandemic Covid-19, the role of parents and online learning

\section{PENDAHULUAN}

Sejak akhir tahun 2019, dunia digegerkan oleh kemunculan virus Corona lebih tepatnya Corona Virus Desease 19 ( Covid - 19 ). Virus yang diduga muncul pertama kali di Wuhan pada bulan Desember 2019 ini telah memporak porandakan seluruh tatanan kehidupan di semua sektor, hampir di seluruh dunia. Covid - 19 telah menjadi bencana global yang mempengaruhi seluruh Negara di dunia ini, tanpa terkecuali. Wabah yang menyerang 
sistem pernapasan ini telah menjadi monster yang sangat menakutkan, karena sampai saat ini dunia kedokteran belum juga menemukan obatnya. Berbagai macam penelitian hingga saat ini terus gencar dilakukan untuk menekan perkembangan virus tersebut.

Tanggal 2 Maret 2020 secara resmi pemerintah Indonesia mengumumkan konfirmasi kasus positif Covid-19, melalui siaran pers yang dilakukan oleh Presiden Joko Widodo. Sejak saat itu setiap hari terjadi penambahan kasus konfirmasi positif Covid-19. Akhirnya pemerintah Indonesia melalui Keputusan Presiden menetapkan bahwa Pandemi Covid-19 ditetapkan sebagai Bencana non alam Nasional. Pemerintah juga membentuk gugus tugas percepatan penanganan Covid-19. Banyak kebiasaan baru yang harus diterapkan dalam kehidupan masyarakat kita. Pemerintah gencar menghimbau kepada seluruh lapisan masyarakat Indonesia untuk menghindari kerumunan, bekerja dari rumah (Work from Home / WFH), belajar dari rumah secara online, beribadah dari rumah, menjaga jarak (Social Distancing ), tidak berjabat tangan, dan rajin mencuci tangan menggunakan sabun . Selain itu, menggunakan masker juga harus dilakukan oleh seluruh masyarakat untuk menghindari penularan Covid-19 ini melalui droplet.

Pemerintah melakukan berbagai upaya untuk memutus mata rantai penyebaran virus Covid-19, yang berakibat pada pembatasan berbagai aktivitas masyarakat. Dunia pendidikan tak luput ikut terdampak oleh bencana Covid-19. Himbauan untuk membatasi aktivitas tentu saja sangat berpengaruh terhadap kegiatan proses belajar mengajar di sekolah / madrasah. Menyikapi hal tersebut Kementerian Pendidikan dan Kebudayaan melalui Surat Edaran Sekretaris Jendral Nomor 15 tahun 2020, yang mengatur tentang pendoman penyelenggaraan belajar dari rumah dalam masa darurat penyebaran Corona Desease 19 ( Covid-19). Sampai dengan akhir tahun pelajaran 2019 / 2020, pandemi belum juga berakhir. Kondisi ini berlanjut hingga tahun pelajaran baru yaitu 2020 / 2021, yang sampai saat ini telah menginjak semester genap. Berbagai upayapun telah dilakukan oleh pemerintah untuk menjamin keberlangsungan pembelajaran daring ini, salah satunya adalah dengan cara memberikan bantuan kuota internet kepada siswa. Dengan demikian diharapkan proses belajar mengajar jarak jauh ini tetap dapat berlangsung, meskipun di lapangan banyak sekali ditemukan kendala.

Pembelajaran daring merupakan pembelajaran yang menggunakan jaringan internet dengan aksesibilitas, konektivitas, fleksibilitas, dan kemampuan untuk memunculkan berbagai jenis interaksi pembelajaran (Sakidin, A., \& Hamidah, A., : 2020). Dalam pelaksanaan pembelajaran daring ini dapat menggunakan berbagai macam aplikasi seperti telephone, live chatt, video conference, zoom atau melalui WhatsApp (Dewi : 2020). Pembelajaran daring dilaksanakan tanpa adanya tatap muka antara guru dengan siswa dan siswa dengan siswa. Artinya pelaksanaannya terpisah oleh jarak ( pembelajaran jarak jauh ). Metode pembelajaran jarak jauh ini memisahkan antara guru dan siswa (Irawati \& Santaria : 2020 ). Keterpisahan tersebut terjadi karena adanya jarak secara fisik dan waktu sehingga kondisi tersebut menyebabkan guru dan siswa tidak dapat melaksanakan kegiatan pembelajaran secara tatap muka (Uno : 2007). Jadi dalam pembelajaran daring ini interaksi yang terjadi antara siswa dengan guru selama proses kegiatan belajar mengajar dihubungkan oleh internet.

Pembelajaran secara on line yang menggunakan jaringan internet ini memerlukan perangkat lunak laptop / PC , atau minimal menggunakan smarphone. Ketersediaan sarana ini menjadi sesuatu yang mutlak, tanpa fasilitas tersebut, siswa akan sulit untuk mengakses kegiatan pembelajaran. Semua guru berusaha menyampaikan pembelajaran semaksimal mungkin baik dalam menyampaikan materi maupun tugas kepada siswa secara online. Namun kenyataan di lapangan dijumpai beberapa kendala antara lain adalah masalah kuota internet, kekuatan signal dilingkungan tempat tinggal yang kurang mendukung. Tidak semua siswa memiliki laptop atau smartphone sendiri. Bentuk kendala yang lain adalah smartphone yang dimiliki oleh siswa tidak didukung oleh fasilitas yang memadai. Banyak siswa yang masih menggunakan fasilitas milik orang tua mereka untuk penyelenggaraan pembelajaran daring ini, sehingga kadang-kadang menjadi kendala tersendiri dalam sebuah keluarga, jika jadwal 
pemakaian bersamaan. Orang tua memegang peranan yang sangat penting selama pembelajaran daring berlangsung, terlebih bagi orang tua yang memiliki beberapa anak yang mengikuti pembelajaran secara daring, dibutuhkan pengaturan waktu yang benar-benar bisa mengakomodir jadwal anak-anaknya dalam pembelajaran.

Menghadapi sistem pembelajaran yang baru ini tentu saja bukan hal yang mudah bagi siswa. Selama ini mereka mengikuti kegiatan pembelajaran secara tatap muka, bertemu langsung dengan guru dan teman-teman mereka setiap hari. Kebijakan dari pemerintah yang mengharuskan anak-anak untuk mengikuti pembelajaran secara daring memaksa mereka untuk beradaptasi dengan kebiasaan baru, yang tentu saja menimbulkan beberapa kendala dalam pelaksanaannya. Jika selama pembelajaran tatap muka anak-anak dalam pengawasan guru selama jam sekolah, maka pada pelaksanaan pembelajaran daring ini pengawasan tersebut akan menjadi kurang efektif. Selama pembelajaran daring anak-anak berada dirumah, dilingkungan keluarga mereka masing-masing. Oleh karena itu orang tua mempunyai peran yang sangat strategis dalam membantu keberhasilan belajar anak-anak mereka. Pengawasan, bimbingan dan pendampingan selama anak mengikuti pembelajaran daring ini akan sangat menentukan capaian hasil pembelajaran anak.

\section{METODE PENELITIAN}

Metode yang digunakan dalam penelitian ini adalah studi literatur. Pada penelitian ini penulis menggunakan berbagai macam literatur yang berasal dari jurnal, berita-berita online, website dan peraturan pemerintah. Penulis tidak melakukan observasi ke lapangan langsung karena masih dalam situasi dan kondisi Pandemi Covid-19. Oleh karena itu analisis data dilakukan dengan mengkaji beberapa sumber informasi yang berasal dari literatur-literatur yang dikumpulkan sesuai dengan tujuan dari penelitian ini. Untuk mengawali penelitian ini, dilakukan penentuan topik, kemudian mengumpulkan dan meninjau literatur-litaratur terkait dan terkini. Data yang diperoleh dianalisis menggunakan metode deskriptif kualitatif dan selanjutnya hasil analisis penjabarannya dilakukan secara mendalam dan terperinci.

\section{HASIL DAN PEMBAHASAN}

Setahun sudah masa Pandemi Covid-19 kita lewati, tentu bukan hal yang mudah bagi dunia pendidikan. Pembelajaran yang biasanya dilakukan secara tatap muka, terpaksa harus dilakukan secara online ( daring ), karena untuk memutus mata rantai penularan Covid-19 ini salah satunya adalah harus menghindari kerumunan dan menjaga jarak. Para pendidik tidak dapat melaksanakan proses pembelajaran tanpa bantuan dari para orang tua, karena siswa berada di rumah, lebih banyak menghabiskan waktunya bersama orang tua mereka di rumah. Kondisi pembelajaran seperti ini tentu saja bukan hal yang mudah baik untuk pihak guru maupun siswa. Pembelajaran daring yang sudah berlangsung selama setahun lebih ini, membutuhkan keterlibatan dan dukungan dari dari berbagai pihak, agar berjalan dengan baik dan tujuan pembelajaran dapat tercapai. Keluarga dan orang tua adalah Madrasah pertama bagi anak-anaknya. Banyak tata nilai dan norma yang telah diajarkan oleh sebuah keluarga sebelum anak-anak mereka masuk sekolah. Pada awalnya orang tua mempunyai peran dalam pembimbingan baik sikap maupun keterampilan yang sangat mendasar misalnya agama, kepatuhan terhadap aturan dan pembiasaan yang baik ( Nurlaeni \& Juniarti : 2017 ). Namun selama Pandemi Covid-19 ini, orang tua mempunyai kiprah peran yang lebih luas, yaitu juga sebagai pendamping akademik bagi anak-anaknya selama mengikuti pembelajaran daring. Orang tua mempunyai porsi waktu yang lebih banyak dibandingkan guru selama masa Pandemi Covid-19 ini, karena anak melakukan pembelajaran dari rumah, sehingga apabila orang tua dapat memainkan perannya yang sangat penting tersebut, maka akan memberikan efek positif bagi anak dalam mengikuti pembelajaran dari rumah. Orang tua menduduki peran yang sangat dibutuhkan oleh anaknya, dalam pembelajaran daring orang tua berperan menjadikan anaknya agar dapat berpartisipasi aktif saat proses pembelajaran berlangsung. Peran tersebut diharapkan dapat memberikan energi kepada anak, menjadikannya merasa 
percaya diri dan mampu mengikuti serta menghadapi kegiatan pembelajaran yang belum pernah ditemukan sebelumnya ( Subarto : 2020 )

Peran keluarga adalah sebagai pondasi pendidikan yang paling pertama bagi anakanaknya. Menurut Hatimah (dalam Lilawati : 2021) bahwa pendidikan merupakan tanggung jawab bersama antara orang tua (keluarga) dan juga guru (sekolah). Dengan demikian pendidikan bukanlah semata-mata tanggung jawab lembaga pendidikan seperti sekolah. Dibutukan kerjasama yang bersinergis antara orang tua (keluarga) dan sekolah (sebagai lembaga formal ) untuk mencapai tujuan pendidikan. Dibutuhkan kesadaran yang tinggi pada seluruh orang tua yang memiliki anak yang masih duduk di bangku sekolah, bahwa peran dan tugas mereka tidak hanya sebatas melakukan pengasuhan dan perawatan saja, namun juga melakukan tugas akademik yang selama ini telah dialihkan kepada pihak sekolah. Sebagian besar orang tua mempunyai pemikiran bahwa tugas mereka telah selesai setelah memasukkan anak-anak mereka ke lembaga pendidikan sekolah (Rosdiana : 2006).

Menurut Winingsih (2020) secara garis besar orang tua mempunyai peran dalam pembelajaran jarak jauh atau pembelajaran daring sebagai berikut 1) sebagai motivator 2) sebagai fasilitator 3) sebagai guru di rumah 4) sebagai pengaruh (director). Dari pemaparan tersebut, orang tua sebagai mitra guru / sekolah mempunyai peran yang sangat penting dalam meningkatkan mutu pendidikan. Selain itu, orang tua juga berperan sebagai pendamping, penjaga, pengembang dan pengontrol serta harus mampu menciptakan lingkungan yang aman, nyaman dan asyik untuk pembelajaran ( Kurniati et al : 2020 ). Selama pembelajaran daring, guru tidak mengalihkan tugas dan tanggung jawab kepada orang tua, akan tetapi ini adalah bentuk kerjasama sinergi antara guru, orang tua dan sekolah. Kerjasama yang terjalin antara guru dan orang tua ini diharapkan dapat mengatasi keterbatasan jarak dan waktu yang menjadi kendala utama bagi guru untuk melakukan pembelajaran tatap muka. Berikut ini diuraikan secara rinci peran orang tua sebagai mitra guru dalam pembelajaran selama Masa Pandemi Covid -19 :

\section{ORANG TUA BERPERAN SEBAGAI MOTIVATOR}

Orang tua harus mampu memotivasi anak dalam segala hal, salah satunya adalah dalam pembelajaran. Berbagai upaya dapat dilakukan oleh orang tua untuk memotivasi anakanaknya antara lain dengan cara memenuhi kebutuhannya, menyemangati dan memberikan pujian. Setiap anak akan mempunyai motivasi untuk melakukan suatu hal, melalui dorongan orang-orang terdekatnya seperti orang tua (Yulianti : 2014)

Dukungan yang diberikan orang tua kepada anaknya sangat berpengaruh terhadap motivasi belajarnya. Hampir semua orang tua membantu memberikan motivasi kepada anaknya selama pelaksanaan pembelajaran daring. Mereka sengaja meluangkan waktunya untuk membantu proses pembelajaran selama masa Pandemi Covid-19 (Hayati : 2020). Dalam pembelajaran daring anak dituntut untuk bisa belajar secara mandiri, mereka yang tidak bisa belajar secara mandiri akan banyak menemui hambatan dan kesulitan. Pendampingan orang tua terhadap anaknya sangat diperlukan agar anak termotivasi dan dapat melakukan pembelajaran mandiri tanpa guru di sekolahnya. Sebagai seorang anak, agar ia dapat mengembangkan potensi-potensi yang dimilikinya melalui pembelajaran membutuhkan seseorang sebagai teman diskusi agar dapat menjawab kesulitan anak dan memotivasi anak ( Pebria : 2019). Selama pembelajaran daring di rumah, pendampingan yang diberikan oleh orang tua terhadap anaknya dapat meningkatkan motivasi belajar anak (Kurniati et al : 2020). Selain itu, pendampingan orang tua juga berfungsi untuk memberikan kepuasan psikologis anak, mengurangi kejenuhan belajar dan meminimalisisr gangguan belajar. Dalam pembelajaran daring ini, tanpa pendampingan dari orang tua, anak bisa saja melakukan halhal lain selain kegiatan pembelajaran, karena anak dapat mengakses internet dengan bebas. Dengan selalu mendampingi anak, orang tua akan dapat menentukan batasan waktu dan konten dalam penggunaan gudged dari internet. Anak akan lebih fokus pada pembelajaran dalam pendampingan dan pengawasan orang tua, sehingga motivasi belajarnya juga 
meningkat (Rachmahana : 2020). Rendahnya motivasi anak untuk belajar, akan menyebabkan anak merasa tertekan dan terpaksa untuk mengikuti pembelajaran. Hal ini akan berdampak buruk pada anak dan anak bisa mengalami stres dan depresi ( KPAI : 2020 ). Kehadiran orang tua yang selalu mendampingi kegiatan pembelajaran anak pada masa pandemi Covid-19 ini sangat diperlukan agar bisa mengetahui kondisi psikologi anak. Saat motivasi anak sedang down untuk mengikuti pembelajaran, orang tua dapat melakukan bimbingan dan tindakan yang diperlukan untuk mengatasinya.

\section{ORANG TUA BERPERAN SEBAGAI FASILITATOR}

Dalam menjalankan perannya ini orang tua harus mampu meluangkan waktunya, tenaga dan kemampuan untuk memberikan fasilitas segala kegiatan anak dalam proses tumbuh kembangnya. Pada lingkungan keluarganya masing-masing, orang tua dapat menciptakan situasi yang kondusif, aman dan nyaman untuk kegiatan pembelajaran di rumah. Dengan demikian anak akan dapat mengikuti pembelajaran dengan perasaan senang dan gembira, tanpa merasa tertekan. Selama pembelajaran daring, orang tua harus dapat memberikan fasilitas penunjang kegiatan belajar mengajar bagi anak-anaknya antara lain seperti laptop, computer atau smatphone. Selain itu orang tua juga harus menyediakan kuota internet yang memadai atau jaringan wifi, agar anak dapat mengakes internet dan mengikuti seluruh rangkaian kegiatan pembelajaran daring.

Adanya sarana dan prasarana pendukung untuk kegiatan pembelajaran daring bagi anak dapat memudahkan mereka memahami system pembelajaran yang berbasis online, sehingga berkontribusi juga terhadap kemajuan belajar siswa (Butar \& Haryanto : 2017). Sebaliknya kurangnya sarana dan prasarana pendukung pembelajaran bagi siswa akan menyebabkan tingkat partisipasi siswa dalam mengkuti kegiatan pembelajaran online juga rendah (Aminoto \& Pathoni : 2014). Namun, selama pembelajaran daring berlangsung, siswa juga membutuhkan sarana lain, selain kebutuhan akses internet. Agar di rumah anak dapat berkembang dan belajar secara optimal, orang tua juga harus memfasilitasi kebutuhan anak yang lainnya. Fasilitas-fasilitas yang dapat diberikan dapat berupa buku-buku teks pelajaran yang disesuaikan dengan kegiatan belajar anak atau disesuaikan dengan tema dan topik yang sedang dipelajari oleh anak (Latif : 2013). Untuk memenuhi kebutuhan ini, para orang tua akan bekerja lebih keras lagi, agar proses pembelajaran anaknya secara online dapat terjamin. Orang tua akan berusaha bagaimana caranya selalu dapat menyediakan kuota / data yang menjadi sarana utama agar anak-anaknya agar dapat mengakses internet.

\section{PERAN ORANG TUA SEBAGAI GURU}

Dalam hal mendidik, mengasuh dan membimbing anak orang tua adalah orang yang paling bertanggung jawab sejak anak-anak mereka dilahirkan hingga tumbuh menjadi dewasa. Sejak dilakukannya pembelajaran secara daring selama masa pandemi Covid-19 akan menjadi tantangan tersendiri bagi seluruh orang tua, sekaligus mengajarkan kepada kita bersama bagaimana untuk menjadi orang tua seutuhnya. Bencana Covid-19 telah mengembalikan peran orang tua sebagai madrasah pertama bagi anak-anaknya (Rahmawati, A. et al : 2021).

Selama pembelajaran daring orang tua di rumah menggantikan peran guru di sekolah. Orang tua tentu saja akan mendidik dan mengajar anak-anaknya dengan cara yang berbedabeda pula. Latar belakang pendidikan orang dalam hal ini akan sangat mempengaruhi cara orang tua dalam mengajar anak-anaknya di rumah selama masa pandemi Covid-19. Orang tua menjadi seorang pendidik, untuk menggantikan peran guru dan menempatkan dirinya pada peran yang sangat sentral dan strategis sebagai "life educator" di rumah. Dengan demikian orang tua akan dapat memanfaatkan kondisi ini sebagai momentum yang tepat untuk hal-hal yang positif bagi anaknya (Anwar : 2013).

Orang tua harus lebih dekat dengan anak-anaknya agar dapat mendampingi anak saat proses pembelajaran daring berlangsung, sehingga diharapkan dapat meningkatkan pemahaman anak terhadap apa yang dipelajarinya secara daring. Banyak anak-anak yang 
mengalami kesulitan dan merasa dalam memahami materi yang diberikan oleh gurunya. Jika orang tua tidak memperhatikan kondisi ini, maka akan melemahkan motivasi anak dan otomatis akan menurunkan tingkat keberhasilan belajar anak. Inilah saatnya orang tua memainkan perannya sebagai pendamping menggantikan guru untuk membantu anak belajar di rumah. Hasil penelitian Indriyani (2021) menyatakan bahwa orang tua menyempatkan meluangkan waktu untuk mendampingi anaknya selama belajar di rumah. Meskipun mereka tidak sepenuhnya menguasai dan memahami materi yang dipelajari oleh anaknya, mereka mengatasinya dengan cara memberikan les tambahan sehingga anak-anak mereka lebih dapat memahami materi yang diberikan oleh gurunya.

\section{KESIMPULAN}

Dari hasil penelitian ini dapat disimpulkan bahwa selama masa pandemi Covid-19 pemerintah telah menetapkan kebijakan pelaksanaan pembelajaran secara daring. Dalam mengikuti kegiatan pembelajaran daring ini, keberhasilan anak tak lepas dari peran orang tua mereka. Perbedaan system pembelajaran tatap muka dengan system daring yang belum pernah ditemukan anak anak sebelum masa pandemi Covid-19 melibatlkan peran orang tua sebagai berikut : (1) orang tua sebagai motivator, karena anak harus belajar secara mandiri, sehingga perlu dorongan dari orang-orang terdekatnya, (2) orang tua sebagai fasilitator, pembelajaran secara daring memerlukan sarana dan prasarana serta kuota data ataupun wifi untuk mendukung dan menjamin keberlangsungan pembelajaran, (3) orang tua sebagai guru, pembelajaran daring menyebabkan terpisahnya guru dengan siswa oleh jarak, sehingga di rumah perannya digantikan oleh orang tua dalam memahami materi pembelajaran.

\section{DAFTAR PUSTAKA}

Anwar, A. (2013). Kontribusi Keluarga Terhadap Pembentukan Karakter Anak ( Studi Perspektif Modal Sosial di Kota Pare Pare ). Kuriositas: Media Komunikasi Sosial dan Keagamaan, 9(1). 57-65

Dewi, W. A. F (2020). Dampak Covid-19 Terhadap Implementasi Pembelajaran di Sekolah Dasar. Educatif : Jurnal Ilmu Pendidikan, 2(1), 55-61. http://doi.org/10.31004/educatif.v2il.89

Hayati, A. S (2020). Peran Orang Tua dalam Meningkatkan Motivasi Belajar Anak dengan Sistem Daring pada Masa pandemi di desa Depokharjo Kebumen. Tasyri' : Jurnal Tarbiyah-Syari'ah, 27 ( 2 ), 23 -32. ejurnal. Kopertis4.or.id

Indriyani, F. \& Yusnani. (2021). Peran Orang Tua dalam Pelaksanaan Pembelajaran Daring pada Siswa Sekolah Dasar di Pulau Rona Kecamatan Bangkinang. Jurnal Pendidikan dan Konseling, 3(1), 90-96. Journal.universitaspahlawan.ac.id

Irawati, R. \& Santaria,R. (2020). Persepsi Siswa SMAN 1 Palopo terhadap Pelaksanaan Pembelajaran Daring Mata Pelajaran Kimia. Jurnal Studi Guru dan Pembelajaran, 3(2), 264-. https://doi.org.10.30605/jsgp.3.2.2020.286

Kementerian Pendidikan dan Kebudayaan RI. 2020. Surat Edaran No 15 Tahun 2020 Tentang Pedoman Penyelenggaraan Belajar dari Rumah dalam Masa Darurat Penyebaran Corona Desease 19 (Covid-19), Jakarta

Kumbarini, Ni Kadek (2020). Analisis Peran Orang Tua dalam Mendampingi Anak di Masa Pandemi Covid-19. Cetta : Jurnal Ilmu Pendidikan 3 (3c-1). http://jayapanguspress.penerbit.org/index.php/cetta/article.view/1130

KPAI. (2020) http://www.medcom.id/pendidikan/tips-pendidikan/PNgYPOOK-butuh-peranorang-tua-cegah-depresi-akibat-belajar-daring 
Kurniati, E., Nur Alfaeni, D. K., \& Andriyani, F. (2020). Analisis Peran Orang Tua dalam Mendampingi Anak di Masa Pandemi Covid-19. Jurnal Obsesi: Jurnal Pendidikan Anak Usia Dini, 5 (1),241-256. https://doi.org/10.31004/obsesi.v5i1.541

Lilawati, Agustien (2021). Peran Orang Tua dalam Mendukung Kegiatan Pembelajaran di Rumah pada Masa Pandemi. Jurnal Obsesi, 5(1), 549-558. https://doi:10.31004/obsesi.v5i1.630

Nurlaeni, N., \& Juniarti Y. (2017). Peran Orang Tua dalam Mengembangkan Kemampuan Bahasa pada Anak Usia 4 - 6 Tahun. Jurnal Pelita PAUD, 2(1), 51-62. https://doi.org/10.33222/pelitapaud.v2i1.196

Pebria, A. (2019). How Maximizingchild Potential. Jakarta: PT Alex Media Komputindo

Rachmahana, R. S. (2020). https://www.republika.co.id/berita/qooOmk430/pentingnya-peranorang-tua-dalam-pembelajaran-daring

Ramawati, Asih, Atik, Indah Novita Wati, Peni Nur Syamsiyah, Yuliana \& Muhammad Faizul Amirudin, (2021). Optimalisasi Peran Orang tua dalam Pembelajaran daring pada Masa Pandemi Covid-19 di Kelurahan Sumber Harta. Edification, 3(2), 153-174

Rosdiana, A. (2006). Partisipasi Orang Tua Terhadap Pendidikan Anak Usia Dini. Jurnal Ilmiah Visi, 1(2), 62-72. https://media.neliti.com/media/publications/259930partisipasi-orang-tua-terhadap-pendidikan-89a4e534.pdf

Sakidin, A \& Hamidah, A. (2020) Research article Pembelajaran Daring di Tengah Wabah Covid-19 ( Online Learning in the Midle of The Covid-19 Pandemic ). https://doi.org/10.22437/bio.v6i2.9759.

Subarto (2020). Momentum Keluarga Mengembangkan Kemampuan Belajar Peserta Didik di Tengah Wabah Pandemic Covid-19. Buletin Hukum dan Keadilan, Vol.4, No 1

Taubah, M. (2016). Pendidikan Anak dalam Keluarga Perspektif Islam. Jurnal Pendidikan Agama Islam ( Journal of Islamic Education Studies ), 3(1), 109. https://doi.org/10.15642/jpai.2015.3.1.109.136

Trisnadewi, K. \& Muliani, NM. ( 2020 ) Pembelajaran Daring di Masa Pandemi Covid-19. Yayasan Kita Menulis

Unicef (2020). Kiat Pengasuhan di Tengah Wabah Virus Corona ( Covid-19). Unicef.org.https://www.unicef.org/indonesia/id/coronavirus/kiat-pengasuhancovid19\#top

Winingsih, Endang. (2020). Peran Orang Tua dalam Pembelajaran Jarak Jauh. April 2, 2020. Poskita.co : https://poskita.co/2020/04/02/peran-orang-tua-dalampembelajaran-jarak-jauh/

Yuliani, T. R. (2014). Peranan Orang Tua dalam Mengembangkan Kreativitas Anak Usia Dini. Jurnal Empowerment, 4(1). 11-24. https ://ejournal.stikipsiliwangi.ac.id/index.php/empowerment/article/view/569/386 